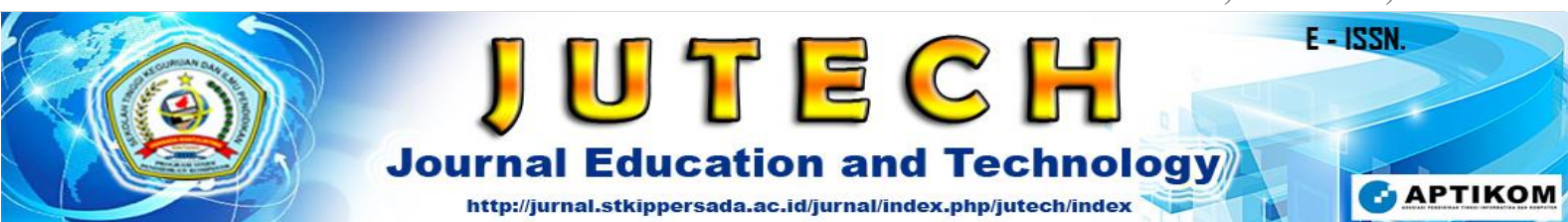

\title{
PENGEMBANGAN MEDIA PEMBELAJARAN BERBASIS MACROMEDIA FLASH PADA PEMBELAJARAN TEMATIK KELAS IV TEMA 6 SUB TEMA 1 AKU DAN CITA-CITAKU
}

\author{
Antonius Edy Setyawan ${ }^{1}$, Warkintin ${ }^{2}$, Y. Januariko ${ }^{3}$ \\ ${ }^{1}$ Program Studi Pendidikan Komputer, STKIP Persada Khatulistiwa Sintang \\ ${ }^{2}$ Program Studi Pendidikan Guru Sekolah Dasar, STKIP Persada Khatulistiwa Sintang \\ ${ }^{3}$ Program Studi Pendidikan Guru Sekolah Dasar, STKIP Persada Khatulistiwa Sintang \\ email:edysetyawan.200286@gmail.com,warkintin1984@yahoo.co.id,yjanuariko@mail.com
}

\section{Informasi Artikel}

Riwayat artikel :

Disubmit : 27 Maret 2020

Direvisi : 6 April 2020

Diterima : 10 April 2020

Dipublikasi : Juni 2020

Keywords:

Development, Learning

Media, Macromedia Flash
The purpose of this research are to find out the development procedure which is conducted by the researcher on learning media based on macromedia flash 8 in class IV elementary school. This ressearch development is arranged based on the deveopmental stages by Luther, which is has 6 stages, namely (1) Concept (2) design (3) Material collecting (4) Assembly (5) Testing (6) Distribution. The data gathering tools that used are, media expert validation sheets, material expert validation sheets, and students response questionnaire sheets. Learning activity in the classroom are using macromedia flash 8 learning media, teacher lectures, and interactions with students. The results of media validators are $83 \%$, categorized as "good" results, the results of material validators are $86 \%$, categorized as "very good". The results of student's questionnarie respose in beta test are 82\%, categorized as "good". Therefore it could be concluded the Development of Learning Media Based on Macromedia Flash on Thematic Learning Class IV Theme 6 Subtheme 1 Me and My Ideals are proper to use.

\section{ABSTRAK}

Tujuan penelitian ini adalah untuk mengetahui bagaimana kelayakan

Kata Kunci:

Pengembangan, Media

Pembelajaran,

Macromedia Flash media pembelajaran berbasis Macromedia Flash 8 di kelas IV Sekolah Dasar. Penelitian pengembangan ini disusun berdasarkan langkah pengembangan dari Luther, dimana terdapat 6 tahap, yaitu: (1) concept, (2) design, (3) material collecting, (4) assembly, (5) testing, dan (6) distribution. Pengumpulan data menggunakan lembar angket dan dokumentasi. Alat pengumpul data berupa lembar validasi ahli media, lembar validasi ahli materi, dan lembar angket respon siswa. Kegiatan pembelajaran di kelas menggunakan media pembelajaran berbasis macromedia flash 8, ceramah guru dan interaksi dengan siswa. Hasil validasi ahli media sebesar 83\%, berkategori "baik", hasil validasi ahli materi sebesar 86\%, berkategori "sangat baik". Hasil angket tanggapan siswa di sekolah adalah $82 \%$ berkategori "baik". Dengan demikian dapat disimpulkan bahwa Pengembangan Media Pembelajaran Berbasis Macromedia Flash Pada Pembelajaran Tematik Kelas IV Tema 6 Sub Tema 1 Aku Dan Cita-Citaku dinyatakan layak digunakan. 


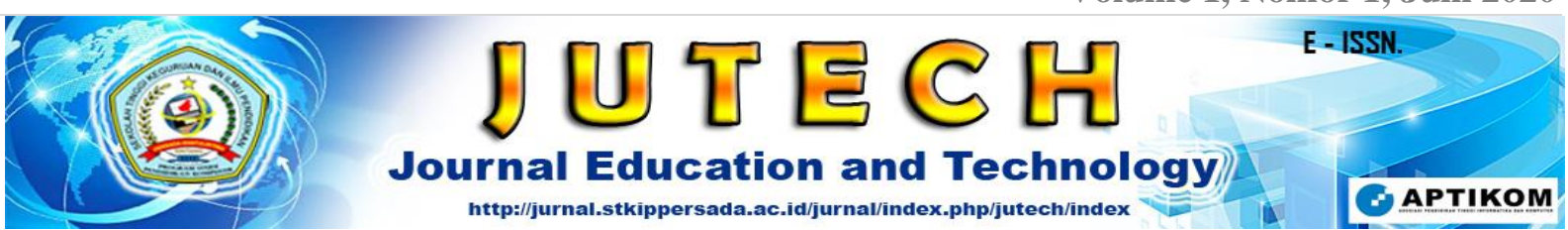

\section{PENDAHULUAN}

Kemajuan zaman telah memberikan begitu banyak perubahan bagi peradaban manusia saat ini. Banyak aspek kehidupan manusia yang menjadi jauh lebih baik seiring perkembangan zaman. Fakta sejarah membuktikan ketika James Watt pada tahun 1765 pertama kali berhasil mengembangkan dan memperbaiki versi mesin uap buatan Newcomen, dan berhasil merubah kehidupan seluruh masyarakat Inggris bahkan dampaknya membawa Inggris dan bangsa Eropa lainnya kedalam masa revolusi industri dan menjadi sangat maju.

Penemuan ini merupakan contoh kecil bagaimana sebuah inovasi pengembangan yang dilakukan seseorang mampu memberikan dampak yang sangat signifikan bagi peradaban manusia. Revolusi industri tidak hanya menjadikan masyarakat lebih efektif dalam pekerjaan, dan membantu para buruh membuat produksi massal lebih cepat, namun dengan adanya revolusi industri ini, membuat setiap aspek kehidupan masyarakat menjadi lebih maju, baik itu aspek ekonomi, sosial, budaya, politik, pendidikan, maupun komunikasi. Hal tersebut bisa tercapai karena adanya inovasi, adanya pengembangan yang dilakukan oleh James Watt, karena masysarakat yang selalu ingin menjadi lebih maju. Kemajuan-kemajuan ini mengalami lompatan yang begitu jauh ketika manusia berhasil menemukan teknologi Komputer dan internet, dimana pesan pertama via internet yang berhasil dilakukan oleh sebuah jaringan komputer pertama yang diciptakan oleh ARPA (Advanced Research Project Agency) Departemen Pertahanan Amerika Serikat dengan menggunakan jaringan ARPANET (Advanced Research Project Agency Network) pada tahun 1969. Dengan hadirnya komputer dalam lingkup kehidupan manusia berhasil membawa angin segar baru dalam pola kehidupan masyarakat. Dimana dalam kehidupan industri dan produksi sudah sangat marak ditemukan penggunaan robot yang sudah terkomputerisasi dalam melakukan pekerjaan, bahkan ada robot di Jepang yang bertugas menjadi receptionist di hotel. Dalam bidang komunikasi juga sangat erat kaitannya dengan teknologi dimana dalam berkomunikasi lebih sering menggunakan fasilitas komunikasi dalam jaringan.

Begitu pula dalam dunia pendidikan, peranan kemajuan teknologi sudah memberi dampak yang begitu terasa bagi civitas akademis. Dalam hal ini baik pihak pendidik maupun peserta didik sama-sama merasakan manfaat langsung dari perkembangan teknologi ini. Guru dan siswa sama-sama semakin mudah mengakses informasi yang berkaitan dengan pembelajaran. Siswa semakin mudah menemukan bahan ajar baginya karena banyak sumber belajar yang bisa didapatnya hanya dengan one touch dan semua yang ingin diketahui terdapat dalam satu perangkat. Begitu pula guru semakin banyak pilihan dalam 


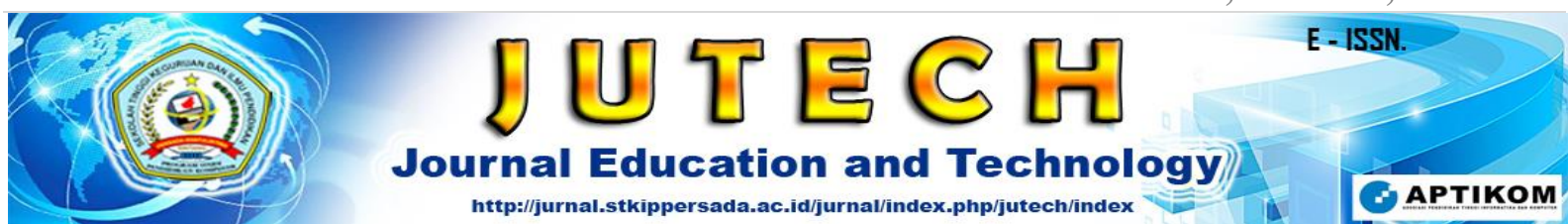

mengajar, karena banyak model-model pembelajaran yang unik kini telah ditunjang dengan media-media hasil kemajuan teknologi, sehingga guru sangat dimudahkan dalam mengajar.

Salah satu media pembelajaran yang saat ini marak digunakan adalah media multimedia audio visual berbantu projector. Media pembelajaran seperti ini dipilih tentu karena adanya berbagai pertimbangan, salah satunya adalah dengan adanya gambar dan audio diharapkan peserta didik dapat memiliki pemahaman yang lebih mendalam mengenai materi yang diajarkan oleh guru. Selain itu, media pembelajaran seperti ini juga mengefektifkan pekerjaan guru dalam mengajar, sehingga guru tidak harus sepenuhnya menjadi pusat dalam penyampaian materi. Hal ini sesuai dengan konsep kurikulum 2013 dimana guru tidak lagi menjadi pusat pembelajaran, melainkan guru menjadi fasilitator dan membimbing siswa dalam pembelajaran.

Pilihan media yang digunakan juga banyak variannya, mulai dari penggunaan Microsoft Words, Microsoft Powerpoint, video dokumentasi, audio pembelajaran, film pendek, maupun penggunaan aplikasi Macromedia Flash 8. Dengan hadirnya banyak pilihan tersebut maka guru dan siswa dapat menjadi kreatif dalam merangkai pembelajaran sehingga dapat meningkatkan hasil belajar akademik siswa.
Namun terdapat kontradiksi di lapangan, meskipun sudah sangat banyak pilihan media yang dapat digunakan dalam proses belajar mengajar, tetapi kebanyakan guru di sekolah masih menggunakan cara-cara yang konvesional sehingga hal ini mengakibatkan hilangnya potensi pembelajaran yang lebih bermakna dan bervariasi, yang pada akhirnya akan menyebabkan pembelajaran di kelas menjadi tidak maksimal. Selain hal tersebut, dengan adanya banyak pilihan tadi membuat para pendidik menjadi jumawa dan merasa puas dengan alat bantu yang sudah ada. Padahal dengan adanya banyak varian dari media pembelajaran hendaknya guru dapat menjadi lebih kreatif lagi dalam mengembangkan kembali apa yang sudah ada, sehingga apa yang sudah ada dapat menjadi lebih baik lagi. Terlebih lagi saat ini semua civitas akademik sudah hampir sepenuhnya menguasai mengenai perangkat elektonik portable seperti smartphone, tabs, laptop, maupun komputer pada umumnya. Sehingga sangat disayangkan apabila dalam kegiatan pembelajaran komponen-komponen yang memiliki peluang untuk meningkatkan keberhasilan belajar siswa di sekolah, menjadi terbuang sia-sia. Hal ini sejalan dengan pernyataan Pribadi (2017: 26) Penggunaan media pembelajaran akan mendorong keterlibatan siswa dalam melakukan proses belajar. Keterlibatan siswa dalam melakukan proses belajar akan mendorong munculnya sikap positif terhadap 


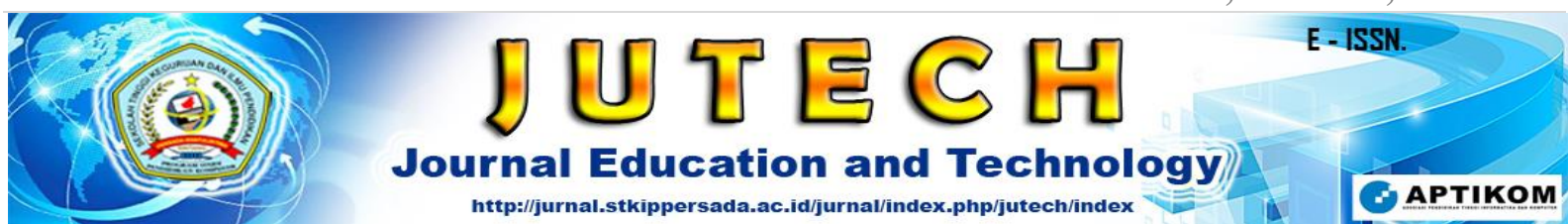

isi atau materi pembelajaran.Hal ini tentu saja akan dapat memudahkan siswa dalam memahami materi atau substansi yang telah dipelajari

Salah satu cara memanfaatkan kecanggihan yang sudah ada tersebut adalah dengan menggunakan aplikasi macromedia flash. Macromedia flash 8 merupakan salah satu aplikasi prodak dari Adobe yang dapat difungsikan untuk membuat animasi, desain web, grafis, maupun audio visual. Macromedia flash 8 menjadi pilihan karena sampai saat ini masih sangat jarang adanya ditemukan pemanfaatan aplikasi ini dalam kegiatan pembelajaran. Selain itu macromedia falsh juga bersifat portable.

Pengamatan yang dilakukan oleh di Sekolah Dasar Negeri 9 Beluis Lelam pada tanggal 18 Febuari 2019 mendapati hal yang cukup menarik perhatian, dimana sekolah tersebut sudah dilengkapi dengan fasilitas listrik yang memadai serta memiliki projector yang sudah dibagikan oleh dinas pendidikan setempat ke sekolah. Selain itu guru di sekolah tersebut sudah memiliki kemampuan untuk menggunakan perangkat elektronik berupa laptop dengan cukup baik. Dengan bekal ketiga hal tersebut tentunya tidak ada alasan bagi pendidik untuk tidak menggunakan alat bantu pembelajaran yang sudah tersedia tersebut sebagai sarana bagi guru untuk menciptakan suasana belajar yang baru bagi siswa. Pada proses pembelajaran, penyajian materi secara konkret sangat dibutuhkan pada siswa sekolah dasar. Kebutuhan akan situasi kongkret mampu menyajikan aktivitas mental siswa, terutama pada materi-materi yang terasa absurd.

Akan tetapi dengan adanya perangkat yang sudah tersedia tersebut, sayangnya hal ini tidak dimanfaatkan dengan baik oleh pendidik, dimana saat pembelajaran guru tidak menggunakan kelebihan-kelebihan yang telah ada sehingga mengakibatkan pembelajaran di kelas menjadi tidak efektif. Dengan adanya listrik yang menyala siang malam, laptop serta projector maka hal ini merupakan modal awal yang sangat bagus bagi peneliti untuk mengemangkan media pembelajaran berbasis macromedia flash 8 di sekolah dasar.

Berdasarkan fakta di lapangan dan pertimbangan-pertimbangan tersebut, maka peneliti tertarik untuk menegembangkan media pembelajaran berbasis macromedia flash 8 ini dalam pembelajaran tematik kelas IV tema 6 , sub tema 1, dalam upaya untuk mengetahui apakah media yang dikembangkan peneliti layak dan pantas dijadikan media pembelajaran bagi siswa SD, terkhusunya pada siswa kelas IV SD.

\section{METODE PENELITIAN}

Penelitian yang dilakukan ini meruakan penelitian pengembangan atau dalam bahasa Inggrisnya Research \& Develoement. Menurut Sugiyono (2015: 297), "Penelitian dan pengembangan adalah metode penelitian yang digunakan untuk menghasilkan produk 


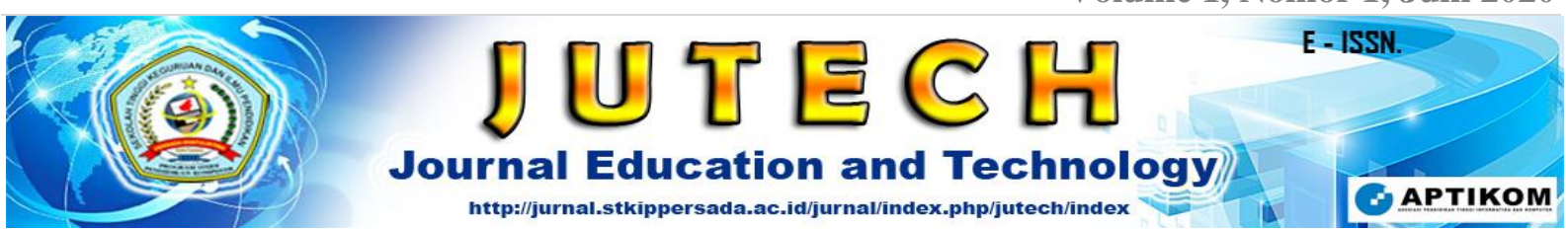

tertentu, dan menguji keefektifitasan produk tersebut".. Model pengembangan yang digunakan dalam penelitian ini adalah model pengembangan Luteher (Binanto: 259), atau yang sering disebut dengan Multimedia Development Life Cycle, yang mana melalui enam tahapan, yakni: concept, design, material collecting, assembly, test, distribution.

\section{Subjek Uji Coba}

Subjek penelitian ini adalah siswa kelas IV di 2 sekolah dasar yang tersebar di gugus 1 satuan pendidikan di kecamatan Seberuang, yaitu SDN 9 Beluis, dan SDN 04 Bati, dengan jumlah peserta didik masing-masing sekolah berjumlah 15 peserta didik,. Uji coba dilakukan dengan memberikan materi di kelas berbantuan media pembelajaran berbasis macromedia flash 8 yang telah dikembangkan, kemudan diberi angket.

\section{Instrumen Pengumpulan Data}

Pengumpulan data dalam penelitian pengemangan media pembelajaran berbasis Macromedia Flash 8 ini adalah dengan (1) Lembar Kusioner, (2) Angket. Alat yang digunakan untuk mengumpulkan data adalah (1) Lembar Angket Penilaian Ahli (2) Angket Siswa (3) Foto.

Lembar angket penilaian ahli digunakan untuk mengetahui hasil validasi dari ahli media dan ahli materi, kemudia lembar angket siswa dingunakan untuk mengetahui bagaimana respon siswa terhadap prodak media pembelajaran yang dikembangkan.

\section{Teknik Analisis Data}

Teknik analisis data dilakukan dengan menggunakan teknik analisis kuantitatif, yaitu sebagai berikut. (1) Analisis Data Penilaian Validator ahli, (2) Analisis Data Tanggapan Siswa. Analisis data penilaian validator ahli, dan tanggapan siswa dihitung dengan menggunakan rumus persentase

\section{HASIL DAN PEMBAHASAN Hasil Penelitian}

Langkah pengembangan yang digunakan adalah dengan model Luther yang melalui enam tahapan, yakni (1) concept (2) design (3) material collecting (4) assembly (5) testing dan (6) distribution.

Tahap concept (konsep) yaitu menunjukan tujuan aplikasi ini dibuat, yaitu untuk mebuat media pembelajaran berbasis macromedia flash 8 untuk siswa kelas IV pada tema 6 sub tema 1. Tahap mengkonsepkan media sangat esensial karena pada tahap ini akan menentukan kepada siapa, dan apa tujuan media pembelajaran ini dikembangkan. Media pembelajaran ini ditujukan untuk guru guna menambah varian media pemelajaran yang bisa digunakan oleh guru saat mengajar peserta didik di kelas, khususnya bagi peserta didik kelas IV sekolah dasar pada pembelajaran tematik tema 6 sub tema 1 tentang aku dan citacitaku.

Tahap design (desain) adalah membuat spesifikasi secara rinci mengenai model proyek, gaya, dan kebutuhan material untuk 


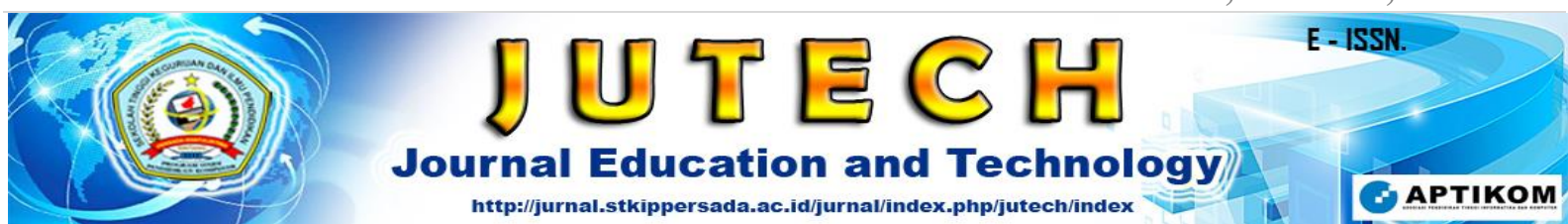

proyek. Spesifikasi dibuat cukup rinci sehingga pada tahap berikutnya,yaitu material collecting dan assembly tidak dibutuhkan keputusan baru, tetapi menggunakan apa yang sudah ditentukan pada tahap design. Namun demikian, seiring berjalannya pengembangan dimungkinkan terjadinya penabahan maupun pengurangan material pada pengerjaan proyek.

Desain model media pembelajaran ini dibuat dengan ukuran layar $800 \times 600$ pixel, dan dapat dioperasikan pada perangkat yang sudah terinstall aplikasi maromedia flash. Dalam pembuatnan media, penulis menggunakan beberapa perangkat aplikasi yang tersedia secara gratis maupun berbayar dari beberapa depelover/pengembang. Untuk aplikasi utama penulis menggunakan macromedia flash 8. Pengguanaan macromedia flash 8 dkarenakan versi macromedia ini bisa dikatakan cukup ringan dan user friendly bagi pengguna umum, serta dengan ukuran yang tidak terlalu besar, menjadikannya tidak membutuhkan spesifikasi laptop/komputer yang besar maka aplikasi ini sangat cocok bagi pengguna perangkat kelas standar

Berikut spesifikasi macromedia flash, yaitu:

1) sistem operasi minimum: Apple $\operatorname{MacOS} X$ 10.3, Microsoft Windows 2000/XP

2) Tipe prosesor: Pentium III, PowerPC G3

3) Kecepatan prosesor: $600 \mathrm{~Hz}, 800 \mathrm{~Hz}$

4) Ukuran RAM minial: $256 \mathrm{MB}$,

5) Hard drive minimal: $360 \mathrm{MB}, 710 \mathrm{MB}$ )
Dalam membuat media pembelajaran, diperlukan banyak raw component yang diperlukan, salah satu yang utama adalah simbol, baik itu berupa tombol, bar, border, maupun background. Untuk itu penulis menggunakan adobe photoshop CS6 untuk membuatnya.

Selain memuat simbol dan gambar, didalam media pembelajaran yang digunakan juga menggunakan audio saat digunakan. Sehingga dalam mengolah audio, penulis menggunakan aplikasi audacity.

Media pembelajaran yang diciptakan nantinya akan ditujukan untuk peserta didik kelas IV sekolah dasar. Oleh karena itu tampilan media pembelajaran dirancang semenarik mungkin, dengan faktor utama yang diunggulkan adalah tampilan dan penggunaan warna dalam media.

Kemudian bahan-bahan yang dibutuhkan adalah berupa gambar yang berekstensi png (portable network graphics), file audio berekstensi wav (waveform audio format), Buku siswa kelas IV tema 6 Sub tema 1 tentang Aku dan Cita-citaku, Laptop, dan Perekam audio.

Material collecting (pengumpulan bahan) dapat dikerjakan paralel dengan tahap assembly. Pada tahap ini peneliti mengumpulkan bahan yang dibutuhkan untuk mebuat media, seperti audio, maupun gambar. Bahan yang diambil diciptakan sendiri oleh 


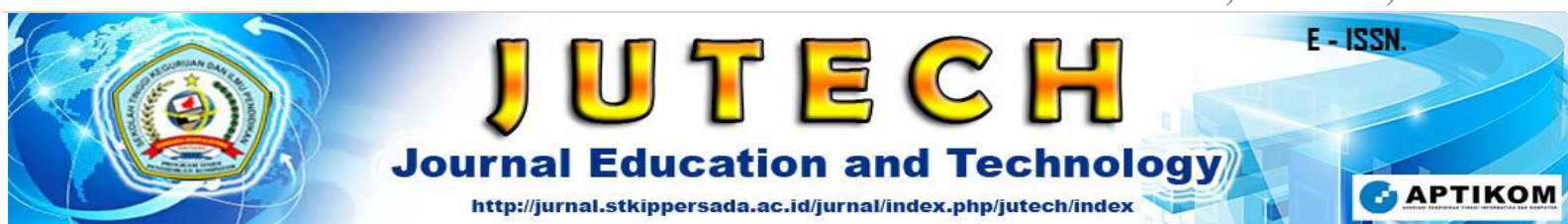

peneliti, selain itu juga terdapat bahan dari sumber lain yang bebas copyright.

Dalam pembuatan simbol maupun gambar per satuan memakan waktu berkisar dari 3-20 menit tergantung tingkat kesulitan item yang dibuat, dengan kisaran ukuran dari $10 \mathrm{~Kb}$ sampai $500 \mathrm{~Kb}$ per simbol/gambar. Kemudian pembuatan audio melalui dua tahap, yaitu dari raw audio dalam format $m p 3$ yang kemudian diedit dan diformat dalam bentuk wav.

Tahap assembly (pembuatan) merupakan tahap dimana seluruh objek multimedia dibuat. Pembuatan media menyesuaikan dengan desain yang telah direncanakan sebelumnya. Setelah semua bahan yang diperlukan terkumpul, maka dilakukan pembuatan media sesuai dengan konsep dan desain dari kerangka media yang hendak dibuat menggunakan aplikasi macromedia flash 8, yang mana outputnya berupa file berekstensi $s w f$, fla, dan exe.

Tahap testing dilakukan setelah tahap pembuatan media selesai. Sebelum dilakukan uji beta, terlebih dahulu dilakukan validasi oleh ahli media dan ahli materi. Setelah itu dilakukan uji beta di sekolah 1 dan sekolah 2 .

\section{Validasi Ahli Media}

Validasi yang dilakukan oleh ahli media terhadap media pembelajaran berbasis macromedia flash 8 melingkupi beberapa aspek, yaitu: aspek rekayasa perangkat lunak, aspek komunikasi audio visual, dan aspek lainnya. Validasi dilakukan oleh validator II dan validaor II. Dimana masing-masing skor dari validator I dan II adalah 41 dan 39, dengan skor maksimal 48, maka jika dipersenkan hasil yang diperoleh dari valdator I adalah $85 \%$ dan hasil yang diperoleh dari validator II adalah $81 \%$. Rata-rata hasil dari validator I dan II adalah $83 \%$ yang artinya media pembelajaran berbasis macromedia flash 8 dikatakan sangat layak digunakan.

Berdasarkan tabel 4.3 dapat diamati bahwa hasil validasi dari ahli media adalah sebesar 41, yaitu sebesar $85 \%$. Kemudian berdasarkan hasil validasi dari validator II mendapat skor sebesar 39, yaitu sebesar $81 \%$.

Aspek komunikasi audio visual dan aspek lainnya, yang meliputi kesesuaian istilah dan symbol/lambang, dan konsistensi peggunaan istilah dan symbol/lambang dengan materi sajian, menjadi sorotan dari hasil validasi kedua ahli media, dimana aspek visual dan audio menjadi permasalahan utama, dikarenakan warna dan tampilan tidak terlalu kontras, dan terdapat beberapa aspek gambar yang dapat mendistraksi isi dari materi, sehingga diperlukan beberapa perubahan.

Dari analisis hasil validasi ahli media yang dilakukan oleh validator media I \& II maka diperoleh skor 80 dan persentase rata-rata $83 \%$. Hal ini menunjukan bahwa media pembelajaran berbasis macromedia flash dikatakan sangat layak digunakan di sekolah.

Tabel 1. Tabel rata-rata validasi ahli media 


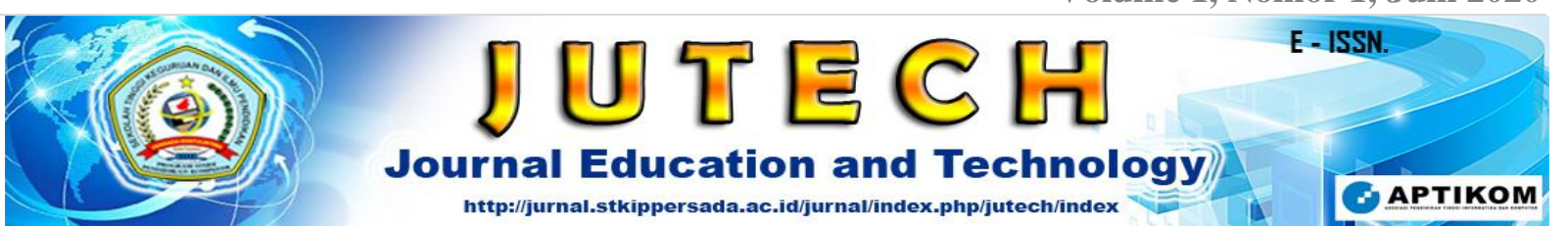

\begin{tabular}{|c|c|c|}
\hline \multirow[b]{2}{*}{ Aspek Penilaian } & \multicolumn{2}{|c|}{ Skor } \\
\hline & $\begin{array}{c}\text { Validator } \\
\text { I }\end{array}$ & $\begin{array}{c}\text { Validator } \\
\text { II }\end{array}$ \\
\hline $\begin{array}{lr}\text { Maintanable } & \text { (dapat } \\
\text { dipelihara } & \text { dan } \\
\text { dikelola } & \text { dengan } \\
\text { mudah) } & \\
\end{array}$ & 3 & 3 \\
\hline $\begin{array}{lr}\text { Usabilitas } & \text { (mudah } \\
\text { digunkan } & \text { dan } \\
\text { sederhana dalam } & \text { dalam } \\
\text { penggunaanya) }\end{array}$ & 3 & 4 \\
\hline $\begin{array}{l}\text { Kompabilitas (media } \\
\text { pembelajaran dapat } \\
\text { diinstalasi) }\end{array}$ & 3 & 4 \\
\hline $\begin{array}{l}\text { Efektif dan efisien } \\
\text { dalam } \\
\text { pengembangan dan } \\
\text { pengguaan media } \\
\text { pembelajaran }\end{array}$ & 3 & 3 \\
\hline $\begin{array}{lr}\text { Komunikatif } & \text { (sesuai } \\
\text { sasaran dan dapat } \\
\text { diterima dengan } \\
\text { keinginan sasaran) }\end{array}$ & 4 & 4 \\
\hline $\begin{array}{ll}\text { Sederhana dan } \\
\text { memikat }\end{array}$ & 3 & 4 \\
\hline $\begin{array}{l}\text { Audio } \\
\text { backsound })\end{array}$ & 4 & 3 \\
\hline $\begin{array}{l}\text { Visual (layout desain, } \\
\text { warna) }\end{array}$ & 3 & 2 \\
\hline $\begin{array}{ll}\text { Media } & \text { bergerak } \\
\text { (animasi) } & \end{array}$ & 3 & 3 \\
\hline $\begin{array}{l}\text { Layout interactive } \\
\text { (ikon navigasi) }\end{array}$ & 4 & 3 \\
\hline $\begin{array}{l}\text { Kesesuaian istilah } \\
\text { dan symbol/lambang }\end{array}$ & 4 & 3 \\
\hline $\begin{array}{l}\text { Konsistensi } \\
\text { peggunaan istilah dan } \\
\text { symbol/lambing } \\
\text { dengan materi sajian }\end{array}$ & 4 & 3 \\
\hline Skor & 41 & 39 \\
\hline$\%$ & $85 \%$ & $81 \%$ \\
\hline Skor Total & 80 & \\
\hline$\%$ Total & $83 \%$ & \\
\hline Kriteria & Sange & layak \\
\hline
\end{tabular}

\section{Validasi Ahli Materi}

Validasi ahli materi meliputi komponen kelayakan isi, dan komponen penyajian. Validasi materi dilakukan oleh validator I dan Validator II, Dimana masing-masing skor dari validator I dan II adalah 42 dan 41, dengan skor maksimal 48, maka jika dipersenkan hasil yang diperoleh dari valdator I adalah $88 \%$ dan hasil yang diperoleh dari validator II adalah $85 \%$. Rata-rata hasil dari validator I dan II adalah $86 \%$ yang artinya media pembelajaran berbasis macromedia flash 8 dikatakan sangat layak digunakan.

Berdasarkan tabel 2 dapat diamati bahwa hasil validasi dari ahli materi I adalah sebesar 42, yaitu sebesar $85 \%$. Kemudian berdasarkan hasil validasi dari validator II mendapat skor sebesar 41 , yaitu sebesar $85 \%$.

Aspek kedalaman materi, aspek konsistensi soal dan jawaban dengan tujuan pembelajaran dengan standar kompetensi/kompetensi dasar/kurikulum, aspek sistematis/runtut/kejelasan urutan, aspek bahasa mudah dipahami bagi siswa dan baku, aspek tidak menimbulkan ambiguitas materi menjadi sorotan dari hasil validasi kedua ahli materi, dikarenakan materi yang diambil hanya berdasar dari buku siswa saja, materi kurang runtut, penggunaan bahasa yang kurang dipahami siswa, dan menimbulkan multitafsir.

Dari analisis hasil validasi ahli media yang dilakukan oleh validator media I \& II maka diperoleh skor 83 dan persentase rata-rata 86\%. Hal in menunjukan bahwa media pembelajaran berbasis macromedia flash dikatakan sangat layak digunakan di sekolah.

Tabel 2. Rata-rata Validasi Ahli Materi

Aspek penilaian Skor




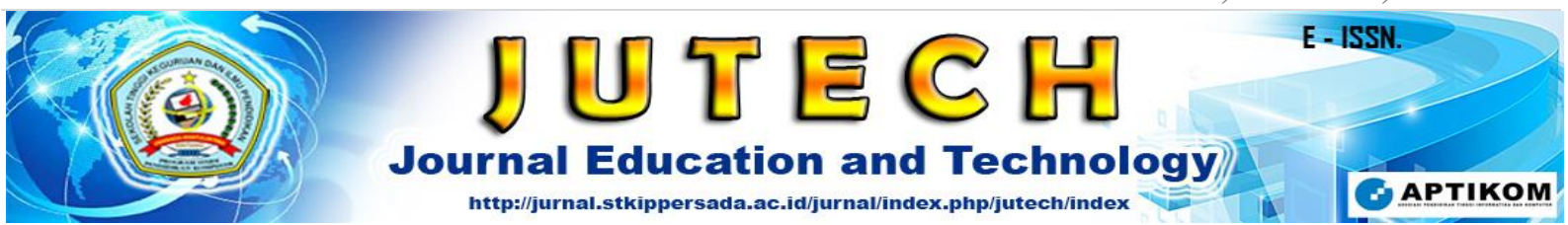

\begin{tabular}{|c|c|c|}
\hline & $\begin{array}{c}\text { Validator } \\
\text { I }\end{array}$ & $\begin{array}{c}\text { Validator } \\
\text { II }\end{array}$ \\
\hline Kedalaman materi & 3 & 3 \\
\hline $\begin{array}{l}\text { Relevansi tujuan } \\
\text { pembelajaran dengan } \\
\text { standar } \\
\text { kompetensi/kompetens } \\
\text { i dasar/kurikulum. }\end{array}$ & 4 & 3 \\
\hline $\begin{array}{l}\text { Kesesuaian tujuan } \\
\text { pembelajaran dengan } \\
\text { standar } \\
\text { kompetensi/kompetens } \\
\text { i dasar/kurikulum. }\end{array}$ & 4 & 3 \\
\hline $\begin{array}{l}\text { Konsistensi soal dan } \\
\text { jawaban dengan tujuan } \\
\text { pembelajaran dengan } \\
\text { standar } \\
\text { kompetensi/kompetens } \\
\text { i dasar/kurikulum. }\end{array}$ & 3 & 3 \\
\hline $\begin{array}{ll}\text { Kebenaran } & \text { dan } \\
\text { ketepatan konsep } & \end{array}$ & 3 & 4 \\
\hline $\begin{array}{ll}\text { Kebenaran } & \text { dan } \\
\text { ketepatan materi } & \\
\end{array}$ & 4 & 4 \\
\hline $\begin{array}{l}\text { Mendorong siswa } \\
\text { untuk mengetahui isi } \\
\text { media pembelajaran }\end{array}$ & 4 & 4 \\
\hline $\begin{array}{lr}\begin{array}{l}\text { Penyajian } \\
\text { komunikatif }\end{array} & \text { bersifat } \\
\text { interaktif } & \text { dan }\end{array}$ & 4 & 4 \\
\hline $\begin{array}{l}\text { Sistematis/runtut/kejel } \\
\text { asan urutan materi }\end{array}$ & 3 & 3 \\
\hline $\begin{array}{l}\text { Kemudahan untuk } \\
\text { dipelajari }\end{array}$ & 4 & 4 \\
\hline $\begin{array}{lr}\text { Bahasa } & \text { mudah } \\
\text { dipahami } \\
\text { dan baku }\end{array}$ & 3 & 3 \\
\hline $\begin{array}{l}\text { Tidak menimbulkan } \\
\text { ambiguitas }\end{array}$ & 3 & 3 \\
\hline Skor & 42 & 41 \\
\hline$\%$ & $88 \%$ & $85 \%$ \\
\hline Skor Total & \multicolumn{2}{|c|}{83} \\
\hline \% Total & \multicolumn{2}{|c|}{$86 \%$} \\
\hline Kriteria & \multicolumn{2}{|c|}{ Sangat Layak } \\
\hline
\end{tabular}

\section{Respon Siswa}

Respon siswa dilihat setelah media pembelajaran berbasis macromedia flash 8 selesai digunakan, dengan cara menyebarkan angket kepada masing-masing siswa. Berikut rata-rata hasil respon siswa di uji beta 1 dan uji beta 2 .

Tabel 3. Persentase rata-rata per aspek di uji beta sekolah $1 \& 2$

\begin{tabular}{|c|c|c|c|c|c|}
\hline Aspek & $\begin{array}{l}\text { No. } \\
\text { Soal }\end{array}$ & $\begin{array}{l}\text { Sekolah } \\
1\end{array}$ & $\begin{array}{l}\text { Sekolah } \\
2\end{array}$ & Total & $\%$ \\
\hline 1 & 1,2 & 29 & 24 & 53 & $88 \%$ \\
\hline 2 & $3,4,5$ & 29 & 34 & 63 & $70 \%$ \\
\hline 3 & 6 & 11 & 12 & 23 & $77 \%$ \\
\hline 4 & $\begin{array}{c}7,10 \\
11\end{array}$ & 37 & 39 & 76 & $84 \%$ \\
\hline 5 & 8,9 & 30 & 27 & 57 & $95 \%$ \\
\hline 6 & 12 & 11 & 13 & 24 & $80 \%$ \\
\hline Total & & 147 & 149 & 296 & \\
\hline \multicolumn{2}{|c|}{ Kriteria } & & & \multicolumn{2}{|c|}{ Sangat Layak } \\
\hline
\end{tabular}

Keterangan:

a) Aspek kejelasan dan ketepatan konten memperoleh skor 88\% dengan kriteria sangat layak digunakan.

b) Aspek ketepatan dan kejelasan tampilan produk media pembelajaran macromedia flash meperoleh skor 70\% dengan kategori layak digunakan.

c) Aspek Ketepatan dalam penggunaan bahasa meperoleh skor $77 \%$ dengan kategori layak digunakan.

d) Aspek kemampuan produk media menimbulkan motivasi belajar meperoleh skor $84 \%$ dengan kategori sangat layak digunakan.

e) Aspek kemampuan produk untuk memperjelas dan mempermudah peserta didik dalam belajar meperoleh skor $95 \%$ dengan kategori sangat layak digunakan. 


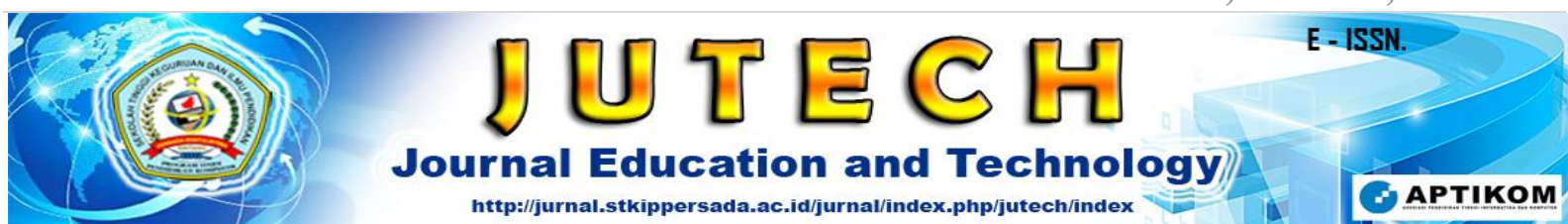

f) Aspek penggunaan produk media memungkinkan siswa mengatasi kesulitan belajar meperoleh skor $80 \%$ dengan kategori sangat layak digunakan.

Persentase tertinggi hasil tanggapan siswa pada setiap aspek pernyataan dalam angket adalah pernyataan angket kemampuan produk untuk memperjelas dan mempermudah peserta didik dalam belajar dengan persentase sebesar 95\%, kemudian disusul aspek kejelasan dan ketepatan konten dengan persentase sebesar $88 \%$, selanjutnya aspek kemampuan produk media menimbulkan motivasi belajar memperoleh persentase sebesar $84 \%$, kemudian aspek penggunaan produk media memungkinkan siswa mengatasi kesulitan belajar memperoleh persentase sebesar $80 \%$, aspek ketepatan dalam penggunaan bahasa memperoleh persentase $77 \%$, dan aspek yang memperoleh skor terendah adalah aspek Ketepatan dan kejelasan tampilan produk media pembelajaran macromedia flash, dengan perolehan eprsentase sebesar $70 \%$.

Media pembelajaran yang telah selesai berekstensi swf, dan dapat digunakan dengan syarat di perangkat laptop/komputer pengguna sudah terinstall program aplikasi macromedia flash 8 keatas. Selain berekstensi swf, media pembelajaran ini juga memiliki output berekstensi exe.

Untuk mendistribusikan media, peneliti menggunakan kaset CD sebagai sarana penyebar luasan media ini, dimana didalamnya terdapat aplikasi media dalam ekstensi exe, swf dan fla, aplikasi macromedia flash 8, buku panduan penggunaan media dalam bentuk pdf, buku panudan yang sudah dicetak, beserta RPP dan silabus.

\section{Pembahasan}

Media pembelajaran berbasis macromedia flash pada pembelajaran tematik kelas IV tema enam sub tema satu di sekolah dasar, dikembangkan dengan menggunakan bebarapa komponen, seperti materi pelajaran, kompetensi dasar, kompetensi inti, dan soal pilihan ganda,gambar png, serta audio wav.

Saat membuka aplikasi media pembelajaran ini, pengguna akan dihadapkan dengan menu start, yang mana jika tombol "mulai" ditekan maka akan mengarahkan angsung ke menu utama. Di dalam menu utama terdapat beberapa komponen, yakni menu, pengaturan, bantuan dan biodata. Masing-masing pilihan tersebut mengarahkan ke frame-frame tertentu. Dengan pemagian ini maka akan mempermudah pengguna untuk melakukan navigasi dalam media yang digunakan.

Komponen menu terdiri dari bebebarapa materi, yakni dari pilihan materi pembelajaran 1 sampai materi pemelajaran 6 . Ketika di klik tiap sub menu pembelajaan terseut akan mengarah pada materi spesifik sesuai dengan buku siswa. Didalamnya sudah terapat, menu kompetesni inti, kompetensi dasar, materi, dan soal pilihan ganda. Hall ini 


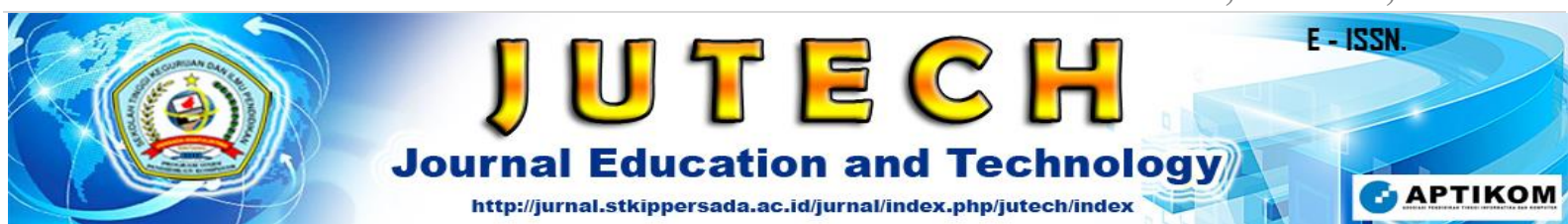

ditujukan supaya guru yang menjadi pengguna media tidak kebingungan dalam menyesuaikan dengan isi media serta menyesuaikannya dengan materi didalam buku siswa.

Selanjutnya menu pengaturan berfungsi untuk mengatur suara. Dimana pengguna bisa memilih untuk menghidupkan musik background atau tidak. Kemudian menu bantuan berisi petunjuk penggunaan media, beserta fungsi dari tombol-tombol yang terdapat dalam media yang digunakan. Terakhir menu biodata, berisi tentang biodata pengguna media yang dikembangkan. Penggunaan musik latar belakang diharapkan dapat membuat peserta didik lebih tertarik dengan materi pelajaran, selain itu dengan adanya menu pengantuan maka guru tidak perlu repot dalam mempelajari media yang digunakan. Semua komponen tersebut disatukan dalam media pembelajaran macromedia flash, yang didistribusikan dalam bentuk $\mathrm{CD}$, beserta dengan buku panduan dalam bentuk print out.

Setelah media pembelajaran selesai dibuat maka selanjutnya dilakukan testing, yang mana meliputi uji alpha dan uji beta. Uji alpha dilakukan oleh validator media dan validator materi, yang mana setelah lolos uji alpha dilanjutkan dengan uji beta di dua sekolah mitra, yakni SDN 09 Beluis Lelam, dan SDN 04 Bati. Uji cooba dilakukn dengan mengimplementasikan media yang telah dibuat dalam pembelajaran di kelas, kemudin untuk melihat tanggapan siswa maka diberikan angket respon siswa setelah pembelajaran selesai.

\section{Kelayakan Media Pembelajaran Menurut Validator}

Validasi dilakukan oleh validator media dan validator materi dengan tujuan untuk mengetahui kelayakan media pembelajaran yang telah dibuat peneliti. Validasi dilakukan dengan menggunakan angket penilaian media dan angket penilaian materi. Validasi ini ditujukan supaya dapat mengetahui kesesuaian, kelebihan, maupun kekurangan media pembelajaran. Sehingga jika dirasa ada yang kurang sesuai maupun kuran maka dilakukan perbaikan media. Hasil angket validator media dan validator materi memperoleh hasil yang memuaskan

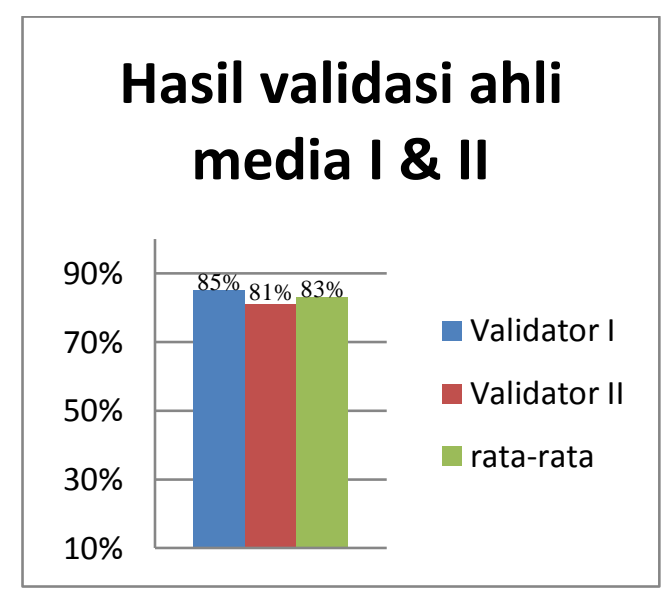

Gambar 1. Hasil validasi ahli media I \& II

Hasil penilaian validator materi I diperoleh persentase sebesar $88 \%$ dan validator materi II diperoleh persetase sebesar $85 \%$, dan rata-rata persentase dari validator media I dan II adalah $86 \%$ dengan kriteria sangat layak dengan bebarapa perbaikan. 


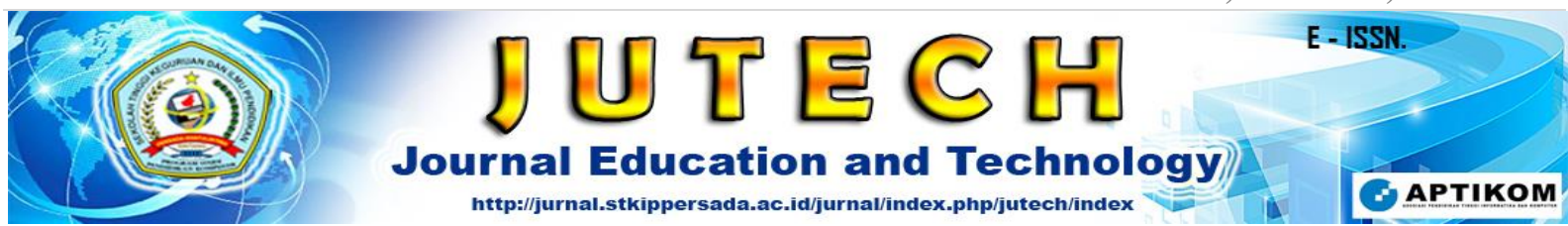

Namun demikian terdapat beberapa perbaikan dari validator materi yang mana meliputi materi, dikarenakan materiinya haya terbatas pada buku ajar siswa, sehingga tidak ada pengemangan lebih lanjut tentang materi yang diajarkan. Berikut hasil anaisis penilaian validator materi pada gambar 2

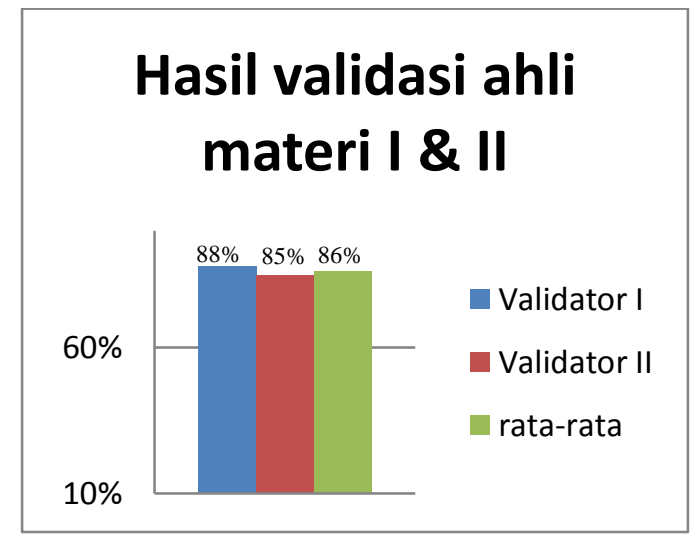

Gambar 2. Hasil validasi ahli materi I \& II

\section{Uji Beta}

Uji beta dilakukan di dua sekolah yakni SDN 09 Beluis Lelam dan SDN 04 Bati. Uji beta dilakukan untuk mengetahui tanggapan siswa terhadap penggunaan media pembelajaran yang sudah dibuat dengan menggunakan angket respon siswa, yang diberikan setelah melakukan kegiatan pembelajaran dengan media.

Tanggapan siswa di SDN 09 Beluis lelam terhadap media pembelajaran berbasis macromedia flash pada pemelajaran tema enam sub tema satu, aku dan cita-citaku memperoleh persentase sebesar $82 \%$ dan hasil respon di SDN 04 Bati memperoleh persentase sebesar $83 \%$. Persentase terbesar berturut-turut sampai terendah yang diperoleh dari respon angket siswa di kedua sekolah tersebut adalah angket nomor loma, satu, empat, enam, tiga, dan dua. Mayoritas siswa setuju dengan pernyataan bahwa kemampuan produk untuk memperjelas dan mempermudah peserta didik dalam belajar, sehingga memperoleh persentase sebesar $95 \%$, kemudian konten jelas dan tepat, menimbulkan motivasi belajar, memungkinkan siswa mengatasi kesulitan belajar, bahsa tepat, dan ketepatan dan kejelasan tampilan produk media pembelajaran macromedia flash meperoleh perseentase terendah yakni $70 \%$ namun masih dalam kategori baik.

Aspek ketepatan dan kejelasan tampilan produk media pembelajaran macromedia flash dan aspek ketepataan dalam penggunaan bahasa menjadi sorotan utama dari hasil angket siswa, dimana kedua aspek tersebut memperoleh skor paling rendah, terutama aspek ketepatan dan kejelasan tampilan produk media pembelajaran macromedia flash. Hal ini dikarenakan dua faktor utama, yaitu audio latar belakang dan jarak proyektor dengan papan tulis yang terlalu dekat. Musik latar belakang menutupi audio utama sehingga audio utama menjadi tidak terlalu terdengar, kemudian karena jarak proyektor dengan papan tulis yang terlalu dekat menyebabkan tampilan media tidak terlihat begitu jelas, sehingga siswa sedikit kesulitan untuk mengamatinya. Kondisi tersbut sejalan dengan teori yang dikemukakan oleh Arsyad (2016:75), yang mengatakan bahwa dalam membuat media pembelajaran perlu memenuhi 


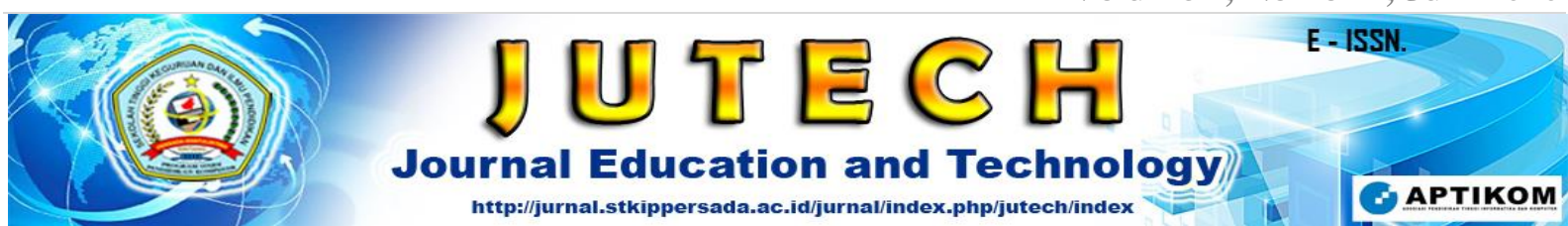

beberapa kriteria, yaitu, sesuai dengan tujuan yang ingin dicapai, tepat untuk mendukung isi pelajaran, praktis, luwes, bertahan, guru trampil menggunakannya, pengelompokan sasaran, dan memilik mutu teknis.

Secara general, media pembelajaran ini telah layak digunakan dalam kegiatan pembelajaran di sekolah, namun demikian masih terdapat halhal yang perlu dibenahi untuk penelitian kedepannya oleh penelti selanjutnya

\section{SIMPULAN}

Berdasarkan hasil penelitian yang dilakukan peneliti maka dapat disimpulkan seperti sebagai berikut:

1. Langkah pengembangan media pembelajaran berbasis macromedia flash 8 ini menggunakan langkah pengembangan model Luther, yang mana melalui 6 tahapan, yaitu concept, design, material colecting, assembly, testing, dan distribution.

2. Validasi dilakukan oleh validator ahli media I \& II, serta validator ahli materi I \& II, yang mana rata-rata hasil dari validasi ahli media adalah $83 \%$, dan hasil dari validator ahli materi adalah $86 \%$ dan dinyatakan sangat layak untuk digunakan di sekolah.

3. Hasil dari angket respon siswa terhadap media pembelajaran berbasis macromedia flash 8 di SDN 09 Bati dan SDN 04 Bati rata-rata sebesar $82 \%$, dan dikatakan sangat layak digunakan.

\section{DAFTAR RUJUKAN}

Arsyad, A. 2016. Media Pembelajaran. Jakarta: PT Rajagrafindo Persada.

Binanto, I. 2010. Multimedia Digital, Dasar Teori Dan Pengembanagnnya.Yogyakarta: $\mathrm{CV}$. Andi Offset

Pribadi, B. 2017. Media dan Teknologi Suatu Pembelajaran. Jakarta: PT Balebet Dedikasi Prima.

Sugiyono. 2015. Metode Penelitian Kuantitatif, Kualitatif dan $R \& D$. Bandung: CV. Alfabeta 